\title{
An exploratory factor analysis of government construction procurement problems
}

\author{
Narong Leungbootnak ${ }^{1, *}$, Tanayut Chaithongrat $^{2}$, and Preenithi Aksorn ${ }^{3}$ \\ ${ }^{1}$ Department of Civil Engineering, Faculty of Engineering, Khon Kaen University, Khon Kaen, Thailand \\ ${ }^{2}$ Faculty of Architecture, Urban Design and Creative Arts, Mahasarakham University, Mahasarakham, Thailand \\ ${ }^{3}$ Faculty of Architecture, Khon Kaen University, Khon Kaen, Thailand
}

\begin{abstract}
This study aims to apply Exploratory Factor Analysis in government construction procurement problems. The questionnaire used in this study to collect data with is the Cronbach's Alpha Coefficient equal to 0.986. The data was collected through Web Survey and 353 participants completed the questionnaires. The data was analysed with the use of percentages, mean, standard deviation, and Exploratory Factor Analysis. When ranking the effect of each component on government construction procurement problems, it was found that the most influential component is procurement process problems, followed by internal and external influence problems, and project management and technical problems, respectively. The top 3 detailed problems on government construction procurement were: 1) Problems arising from fix announcement period, 2) Restrictions according to the regulations that all agencies need to send the announcement details by the approval date of procurement, and 3) Problems arising from fix announcement periods, especially associated to mandatory plans.
\end{abstract}

\section{Introduction}

Government procurement is very important to a country's development because the government must spend the budget for materials to provide public goods such as education, security, facilities, basic infrastructure, safety, etc. It is argued that government procurement is essential to the delivery public services and the operation of government agencies [1]. Therefore, the governments spend budget, is limited solely by the effectiveness of the procurement analysis. However, effective procurement does not necessarily mean buying at the lowest price. Instead, the procurement depends primarily on the objective to help develop industry and technology in the country [2].

In many countries, procurement has developed several aspects rapidly to support the growth of domestic and global economy. Procurement is important as it aids basic and supporting factors of public and private sectors. As a result, the public procurement must adapt and develop rapidly to increase its flexibility. Due to the changes in missions among public sector, private sector, and civil society, the bureaucracy system becomes smaller, but more flexible and effective which makes the public and private processes quicker, more transparent, and more efficient [3]. Thus, government can strengthen the private sector so that both sectors can develop the country, and achieve sustainable growth [4]. Therefore, in the era of technology which plays a main role in every organization, both public and private sectors need to rely on information technology because ample, and rapid upto-date information leads to more efficient work [5].

In each country, the expenditure related to government procurement accounts for $10-15 \%$ of Gross Domestic Product (GDP). Moreover, it is reported that the budget for construction projects is about 2,000 million dollars per year [6]. However, nowadays, the government procurement still cannot meet nor solve effectively the needs of stakeholders. It can be seen from the research and media as a reflection of several procurement problems such as corruption within the government construction procurement projects, procurement cost due to higher than actual cost, the cronyism resulting in poor quality of work, additional expenses or budget losses, and/or poor overpriced materials [5],[7-8].

Therefore, this study aims to examine the components of government construction procurement problems. The public organizations were selected to be samples and investigated using Exploratory Factor Analysis. Moreover, the relationship model was developed by using statistical software to analyse these factors.

\section{Government Procurement Problems}

From the literature reviewed, there were 4 main government procurement problems. The first problem is caused by government officials including both unintended and intended offenses acted by the officials seeking illegal benefits [9]. The second problem arises

\footnotetext{
* Corresponding author: Narongl.fec@gmail.com
} 
from poor planning or not having a plan, unclear work specification details which were not defined in advance nor during the procurement process [10-13] identified the causes of the procurement problems such as execution plan, procurement, tender, contract audit and compliance. The third problem arises from complex rules, regulations, and official letters. The last problem is caused by the corruptions. Based on Tanayut C., Narong L., Preenithi A. \& Patrick M. (2017) [14]., it was found that some government officials were purposely dishonest in seeking benefits from the procurement process, which included violating, distorting, or avoiding regulations and/or laws [15].

\section{Methodology}

This section presents the methodology used in this study as follows.

\subsection{Population and Sample}

The population in this study consisted of 3,025 government construction procurement projects, observed from January 2014 to January 2015. 353 projects were selected to be samples by adopting the sampling method introduced by Yamane at the significant level of $95 \%$. The sample size was defined by considering the basic requirements of Factor Analysis which the acceptable sample size is not less than 300 [16]. Moreover, the samples were randomly selected by adopting Systematic Random Sampling approach [21].

\subsection{Instrumentation and Validity Test}

To create and validate the questionnaire, the researcher defined 45 questions from the review of literature and relevant research. The questionnaire was designed as Likert scale consisting 5 levels which are 5-Strongly agree, 4-Agree, 3-Undecided, 2-Disagree, and 1Strongly disagree, respectively. After that, 5 experts considered the content validity of the questionnaire. According to the experts, only 40 questions were passed, the criteria since the mean scores were between 0.50 to 1.00. After that, the researcher improved the questionnaire and sampled out 30 participants who were not the selected as part of the test model. To test the accuracy of the questionnaire, Cronbach's Alpha Coefficient $(\alpha)$ of the questionnaire was determined. Consequently, the coefficient $(\alpha)$ was 0.986 indicating that the questionnaire was highly reliable.

\subsection{Data Collection}

The researcher collected the data through Web Survey [21] and cooperated with The Comptroller General's Department to disseminate the questionnaires on the website (www.gprocurement.go.th), and sent letters to government agencies selected as samples to participate in the online survey between April to May 2016. As a result, 353 participants completed and returned the questionnaires accounting for $100 \%$ response rate. After the results from the survey were analyzed using statistical technique.

\subsection{Data Analysis}

SPSS from Microsoft Windows, a statistical software application was used for statistical analysis. The analysis was divided into three levels Univariate analysis, Bivariate analysis, and Multivariate analysis. Univariate analysis consists of percentage, mean, standard deviation, skewness and kurtosis to examine the distribution of the government construction procurement problems, and to present the general characteristics of the samples. Bivariate analysis consists of correlation and Pearson Product Moment to examine correlation coefficient between the variables by conducting Bartlett's Test of Sphericity. It was found that the matrix was not an identity matrix which indicated the results could be used for further analysis, considering the variables with coefficient 0.3-0.9 [16]. Lastly, Multivariate analysis was conducted with the use of Exploratory Factor Analysis. The Principal Component Factor was selected to be use with Orthogonal rotation and Varimax method. Factor loadings higher than 0.40 were focused and labelled [16].

\section{Results}

This section presents the methodology used in this study as follows.

\subsection{General Information of the Respondents}

As presented in Table 1, most of the respondents were male $(54.4 \%)$, aged between $41-50$ years $(33.7 \%)$, and have a Bachelor degree $(63.74 \%)$. Furthermore, most of participants are the head of supplies or supplies officer (46.7\%), followed by procurement auditor (22.9\%). Most of the respondents have experienced in the procurement of construction projects for 9.5 years on average, with 7.6 standard deviation. Moreover, most of the projects belong to local government (26.5\%), followed by general government $(34.6 \%)$. 38\% of the projects are in the central part of Thailand. It is also found that the special procurement is adopted most $(34.6 \%)$, followed by tender $(25.8 \%)$, and e-bidding $(24.4 \%)$, respectively. Most of the projects are building construction $(35.1 \%)$, followed by road construction $(34 \%)$.

\subsection{Results of Exploratory Factor Analysis}

According to the results, it was found that KOM (KaiserMeyer-Olkin Measure of Sampling Adequacy) is equal to 0.971 which is very close to 1 . This indicates that the data are suitable for Factor Analysis. From Bartlett's test of Sphericity, if found that Chi-square is equal to 15249.527 with $p$-value less than 0.01 meaning that the correlation matrix is not an identity matrix. Therefore, it can be concluded that all 38 variables are correlated to each other and suitable for Factor Analysis (Table 1). 
Table 1. Validity test of correlation matrix between variables.

\begin{tabular}{|c|c|c|c|c|}
\hline \multirow{2}{*}{ Variable } & \multicolumn{2}{|c|}{ KMO } & \multicolumn{2}{c|}{ Bartlett's Test } \\
\cline { 2 - 5 } & Ideal Value & $\begin{array}{c}\text { Actual } \\
\text { Value }\end{array}$ & $\begin{array}{c}\text { Ideal } \\
\text { Value }\end{array}$ & $\begin{array}{c}\text { Actual } \\
\text { Value }\end{array}$ \\
\hline $\begin{array}{c}40 \\
\text { variables }\end{array}$ & $\begin{array}{c}>0.50 \\
(>0.9=\text { Very good })\end{array}$ & 0.971 & $\begin{array}{c}\text { p-value } \\
<0.05\end{array}$ & $<0.01$ \\
\hline
\end{tabular}

Table 2. The number of components, Eigenvalues, percent and cumulative percent of Eigenvalues of government construction procurement problems.

\begin{tabular}{|c|c|c|c|c|}
\hline Component & $\begin{array}{c}\text { No. of } \\
\text { Items }\end{array}$ & $\begin{array}{c}\text { Eigen } \\
\text { values }\end{array}$ & $\%$ & $\begin{array}{c}\text { Cumulative } \\
\text { \% }\end{array}$ \\
\hline 1 & 13 & 22.340 & 65.704 & 65.706 \\
\hline 2 & 14 & 2.298 & 6.758 & 72.464 \\
\hline 3 & 9 & 1.112 & 3.269 & 75.733 \\
\hline
\end{tabular}

Table 2 presents the number of components, Eigenvalues, percent and cumulative percent of Eigenvalues of government construction procurement problems. All 3 components can explain the total variance which is equal to $75.733 \%$. Each of the 3 components of government construction procurement problems consists of at least 3 variables, so the components satisfied the rule in which each component must contain at least 3 variables. Furthermore, each factor loading variable is greater than 0.4 [16] indicating that all 3 components with 40 variables satisfied the Factor Analysis rule.

Table 3-5, it was found that Component 1, consisting of 13 variables, has a factor loading between 0.548 0.802 . Eigenvalue is 22.340 , and the percent of variance is 65.706. Therefore, it is indicated that 13 variables are the best predictors from component 1 . When comparing Eigenvalue with other components, this component is the most important since it has the highest Eigenvalue. Consequently, this component is named as 'Procurement process problems'.

Table 3. Component 1: Procurement process problems.

\begin{tabular}{|c|l|c|}
\hline Variable & \multicolumn{1}{|c|}{ Text } & $\begin{array}{c}\text { Factor } \\
\text { Loading }\end{array}$ \\
\hline PP1 & $\begin{array}{l}\text { Officers lack the skills to draft TORs } \\
\text { and contracts. }\end{array}$ & 0.736 \\
\hline PP2 & $\begin{array}{l}\text { Officers lack knowledge of the } \\
\text { supplies and other regulations related } \\
\text { to procurement. }\end{array}$ & 0.764 \\
\hline PP3 & $\begin{array}{l}\text { Some officers are worried that the } \\
\text { information will leak. }\end{array}$ & 0.707 \\
\hline PP4 & $\begin{array}{l}\text { There are no clear criteria for defining } \\
\text { performance measures. }\end{array}$ & 0.707 \\
\hline PP5 & $\begin{array}{l}\text { Officers lack precision and are afraid } \\
\text { of rules and regulations. }\end{array}$ & 0.749 \\
\hline PP6 & $\begin{array}{l}\text { Problems arising from fix } \\
\text { announcement periods, especially } \\
\text { associated to mandatory plans. }\end{array}$ & 0.787 \\
\hline PP7 & $\begin{array}{l}\text { Problems arising from fix } \\
\text { announcement period. }\end{array}$ & 0.802 \\
\hline
\end{tabular}

Table 3. (cont.)

\begin{tabular}{|c|c|c|}
\hline Variable & Text & $\begin{array}{c}\text { Factor } \\
\text { Loading }\end{array}$ \\
\hline PP8 & $\begin{array}{l}\text { Restrictions according to the } \\
\text { regulations that all agencies need to } \\
\text { send the announcement details by the } \\
\text { approval date of procurement. }\end{array}$ & 0.794 \\
\hline PP9 & $\begin{array}{l}\text { Problems arising from unclear } \\
\text { clarification. }\end{array}$ & 0.735 \\
\hline PP10 & $\begin{array}{l}\text { Problems arising from inadequate time } \\
\text { for pricing. }\end{array}$ & 0.669 \\
\hline PP11 & $\begin{array}{l}\text { Problems arising from defining the } \\
\text { mid-price, incomplete pricing, no } \\
\text { allowance for loss, and inappropriate } \\
\text { mid-price. }\end{array}$ & 0.623 \\
\hline PP13 & $\begin{array}{l}\text { Problems arising from referring to the } \\
\text { mid-price defined by the Comptroller } \\
\text { General's Department in which the } \\
\text { price material is not updated. }\end{array}$ & 0.548 \\
\hline PP15 & $\begin{array}{l}\text { Lack of accurate procurement } \\
\text { planning }\end{array}$ & 0.568 \\
\hline \multirow{2}{*}{$\begin{array}{c}13 \\
\text { factors }\end{array}$} & Eigenvalue & 22.340 \\
\hline & Percent of variance & 65.706 \\
\hline
\end{tabular}

Table 4. Component 2: Internal and External Influence Problems

\begin{tabular}{|c|c|c|}
\hline Variable & Text & $\begin{array}{l}\text { Factor } \\
\text { Loading }\end{array}$ \\
\hline PP26 & $\begin{array}{l}\text { Approved construction budget is not } \\
\text { enough. }\end{array}$ & 0.515 \\
\hline PP27 & $\begin{array}{l}\text { Changing executive affects, changes in } \\
\text { utility and work progress. }\end{array}$ & 0.617 \\
\hline PP28 & $\begin{array}{l}\text { Problems arising from complex } \\
\text { workflows. }\end{array}$ & 0.518 \\
\hline PP29 & $\begin{array}{l}\text { Officers have negative attitude toward } \\
\text { their colleagues. Problems from } \\
\text { different opinions and conflicts within } \\
\text { the workplace. }\end{array}$ & 0.615 \\
\hline PP31 & $\begin{array}{l}\text { Problems arising from political } \\
\text { impact. }\end{array}$ & 0.735 \\
\hline PP32 & $\begin{array}{l}\text { Problems arising from external audits } \\
\text { such as audit agencies and NGOs. }\end{array}$ & 0.672 \\
\hline PP33 & $\begin{array}{l}\text { Problems arising from contractors not } \\
\text { participating in biding or leaving their } \\
\text { jobs. }\end{array}$ & 0.666 \\
\hline PP34 & $\begin{array}{l}\text { Problems arising from bidders' } \\
\text { complaints in procurement such as } \\
\text { unclear announcement. }\end{array}$ & 0.816 \\
\hline PP35 & $\begin{array}{l}\text { Problems arising from community } \\
\text { complaints. }\end{array}$ & 0.875 \\
\hline PP36 & $\begin{array}{l}\text { Political and social problems such as } \\
\text { protest. }\end{array}$ & 0.887 \\
\hline PP37 & $\begin{array}{l}\text { Economic problems such as rising } \\
\text { material prices. }\end{array}$ & 0.715 \\
\hline PP38 & $\begin{array}{l}\text { Problems from poor contractors who } \\
\text { bid lower than what the mid-price } \\
\text { actually is. }\end{array}$ & 0.646 \\
\hline \multirow{2}{*}{$\begin{array}{c}14 \\
\text { factors }\end{array}$} & Eigenvalue & 2.298 \\
\hline & Percent of variance & 6.758 \\
\hline
\end{tabular}


Table 5. Component 2: Internal and External Influence Problems

\begin{tabular}{|c|l|c|}
\hline Variable & \multicolumn{1}{|c|}{ Text } & $\begin{array}{c}\text { Factor } \\
\text { Loading }\end{array}$ \\
\hline PP16 & Problems arising from delayed work. & 0.679 \\
\hline PP17 & $\begin{array}{l}\text { Problems arising from insufficient } \\
\text { number of procurement officers. }\end{array}$ & 0.664 \\
\hline PP18 & $\begin{array}{l}\text { Problems arising from officers' } \\
\text { potential. }\end{array}$ & 0.717 \\
\hline PP19 & $\begin{array}{l}\text { Problems arising from working with } \\
\text { several difficult functions. }\end{array}$ & 0.721 \\
\hline PP20 & $\begin{array}{l}\text { Problems arising from coordinated } \\
\text { errors. }\end{array}$ & 0.689 \\
\hline PP21 & $\begin{array}{l}\text { Problems of mismatch between } \\
\text { construction models, and incomplete } \\
\text { pricing. }\end{array}$ & 0.633 \\
\hline PP23 & Problems arising from time conflicts. & 0.555 \\
\hline PP24 & $\begin{array}{l}\text { Problems arising from poor } \\
\text { management. }\end{array}$ & 0.629 \\
\hline PP25 & $\begin{array}{l}\text { Problems arising from different } \\
\text { working quality on each function. }\end{array}$ & 0.666 \\
\hline $\mathbf{9}$ & Eigenvalue & $\mathbf{1 . 1 1 2}$ \\
\cline { 2 - 3 } factors & Percent of variance & $\mathbf{3 . 2 6 9}$ \\
\hline
\end{tabular}

These components of problems are in consistent with the government construction procurement problems proposed by Dzuke \& Naude [1] stating that the components are procurement planning, bidding, and contract audit and compliance. Also, the concept of the procurement problem is in consistent with Gardenal [12] stating that the components of procurement problems include supply planning and procurement process.

\section{Conclusions}

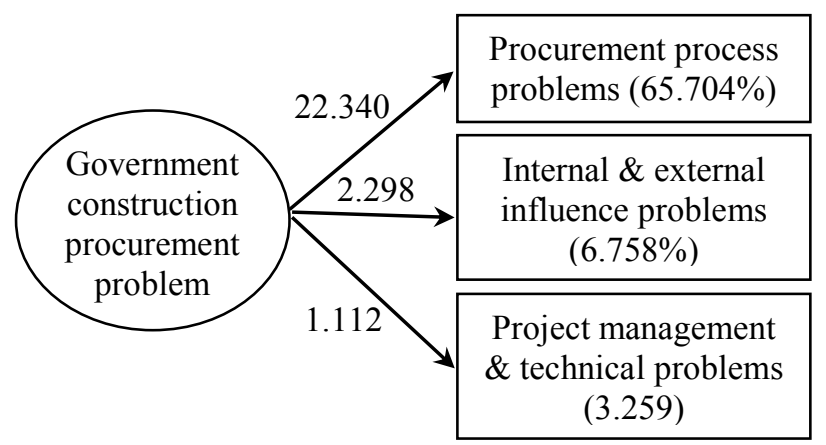

Fig. 1. Summary of component analysis of government construction procurement problems.

According to the factor analysis, there are 3 components affecting government construction procurement projects as presented in Figure 1. When ranking the effect of each component on government construction procurement problem, it is found that the most influential component is procurement process problems accounting for
$65.704 \%$ in explaining the problem with 13 observed variables. Internal and external influence problems is the second influential component accounting for $6.758 \%$ in explaining the problem with 14 observed variables. Lastly, the third influential component is project management and technical problems accounting for $3.269 \%$ in explaining the problem with 9 observed variables.

\section{References}

1. Dzuke, A. \& Naude, M.J.A., JTSCM, 9(1), 1-9 (2015)

2. Wathanam, T., "WTO agreement on government procurement: GPA", TRF, Bangkok, Thailand (2007)

3. NESDB, "The Twelfth National Economic and Social Development Plan, 2017-2021”, Retrieved 10 October 2017, (2017)

4. Walker, H. \& Brammer, S., Supply Chain Management: An International Journal, 14 (2), 128137, (2017)

5. Du, J., Jiao,Y.Y., Jiao, R.J., Kumar, A. \& Ma, M., Proc IEEE IEEM, 1337-1341, (2007)

6. Pimsi, A., PhD Thesis. King Mongkut's University of Technology North Bangkok, (2005)

7. Hazra, J., IJSTM, 7(5), 1364-1368, (2011)

8. McKevitt, D \& Davis, P., IJPSM, 26(6), 469-480, (2013)

9. Licenji, A., ESJ, 11(25), 229-240, (2015)

10. Pesämaa, O., Eriksson, P.E. \& Hair, J. F., IPMA, 27(6), 552-559, (2008)

11. Ameyaw, C., Mensah, S. \& Osei-Tutu, E., IJCSCM, 2(2), 55-65, (2012)

12. Gardenal, F., JOPP, 13(2), 215-242, (2013)

13. Dzuke, A. \& Naude, M.J.A., JTSCM, 9(1), 1-9, (2015).

14. Tanayut C., Narong L., Preenithi A. \& Patrick M., ITJEMAST, 8(3), 221-231, (2017)

15. Dza, M., Fisher, R., \& Gapp, R., PAR, 2(2), 49-57, (2013)

16. Field, A., "Discovering statistics using IBM SPSS statistics”, SAGE Publications, London, UK, (2013)

17. Chadcham, S. \& Kornpeipanee, S., Journal of Educational Research and Measurement, 1(2), 1-24, (2003)

18. Kim, J.O., \& Mueller, C.W., "Factor analysis: Statistical Methods and Practical Issues", Beverly Hills, CA: Sage, (1978)

19. Hooper, D., Coughlan, J., Mullen, M., EJBRM, 6(1), 53-60, (2008)

20. Fabrigar, L.R., Wegener, D.T., MacCallum, R.C., \& Strahan, E.J., Psychological Methods, 4 (3), 272299, (1999)

21. Neuman, W.L. "Social research methods: qualitative and quantitative approaches", Printed in United States of America, (2006) 